\title{
REKAM JEJAK KIMIA PERMUKAAN SIO2 PRODUKSI FASILITAS TEKNOLOGI PEMURNIAN ZIRKONIUM PSTA
}

\section{SURFACE CHEMISTRY TRACKING OF SIO 2 PRODUCT OF PSTA-ZIRCONIUM PURIFICATION TECHNOLOGY FACILITY}

\author{
Muzakky \\ Pusat Sains dan Teknologi Akselerator, BATAN \\ J. Babarsari Kotak Pos 6101 ykbb, Yogyakarta 55281 \\ e-mail: muzakkyi@batan.go.id
}

Diterima 24 November 2017, diterima dalam bentuk perbaikan 19 Januari 2018, disetujui 3 Maret 2017

\begin{abstract}
ABSTRAK
REKAM JEJAK KIMIA PERMUKAN SIO 2 PRODUKSI FASILITAS TEKNOLOGI PEMURNIAN ZIRKONIUM PSTA. Telah dilakukan rekam jejak kimia permukan $\mathrm{SiO}_{2}$ produksi fasilitas teknologi pemurnian zirkonium PSTA. Tujuan dari penelitian ini adalah untuk melakukan perekaman jejak gugus silanol (ESi-OH), siloksan (三Si-O-SiE) serta grup air (OH) di permukaan produk hasil pemurnian $\mathrm{SiO}_{2}$ gel. Parameter proses pemurnian memakai variable fungsi suhu, waktu dan konsentrasi asam HF. Rekam jejak $\mathrm{SiO}_{2}$ gel dilakukan dengan Fourier- transform infrared (FT-IR) spectroscopy dan deteksi desorpsi pengotor $\mathrm{Fe}^{3+}$ memakai absorpsi serapan atom (AAS). Hasil Pemurnian $\mathrm{SiO}_{2}$ gel dengan pelarut campuran $\mathrm{HF}$ dan $\mathrm{HCl}$, maksimal dilakukan pada komposisi $1 \% \mathrm{HF}$ dan $1 \mathrm{~N} \mathrm{HCl}$ pada suhu $80{ }^{\circ} \mathrm{C}$ selama 8 jam. Pada keadaan proses pemurnian $5 \% H F$, suhu $100{ }^{\circ} \mathrm{C}$ dan waktu kontak 10 jam akan merusak gugus silanol, siloksan dan grup air. Keberhasilan pemurnian perlu dilakukan rekam jejak FTIR pada hasil pemurnian di panjang gelombang 3448 $\mathrm{cm}-1,1635 \mathrm{~cm}-1,1103 \mathrm{~cm}-1$ dan $462 \mathrm{~cm}^{-1}$ yang merupakan karakteristik dari SiO ${ }_{2}$. Dengan munculnya puncak di sekitar panjang gelombang $1103 \mathrm{~cm}^{-1}$ dapat diprediksi cuplikan terdapat mineral jenis a quart. Proses pemurnian $\mathrm{SiO}_{2}$ gel yang dilakukan pada kondisi optimal, ternyata dapat menghilangkan pengotor dalam filtrat sebesar 60,4m// Fe ${ }^{3+}$ dari $100 \mathrm{mg} / \mathrm{gr}$ residu $\mathrm{SiO}_{2}$
\end{abstract}

Kata kunci: $\mathrm{SiO}_{2}$ gel, silanol, siloksan, grup air, FTIR, AAS.

\section{ABSTRACT}

SURFACE CHEMISTRY TRACKING OF $\mathrm{SiO}_{2}$ PRODUCT OF PSTA-ZIRCONIUM PURIFICATION TECHNOLOGY FACILITY. Surface chemistry tracking of $\mathrm{SiO}_{2}$ product of PSTA- Zirconium Purification Technology Facility had been done. The objective of the investigation is to track the functional groups of xylanol (ESi-OH), siloxane (三Si-O-SiE) as well as water $(\mathrm{OH})$ at the surface product of $\mathrm{SiO}_{2}$ gel. The processing parameters conducted were temperature, time and concentration of $\mathrm{HF}$ acid. Tracking of $\mathrm{SiO}_{2} \mathrm{gel}$ was conducted by using Fourier- transform infrared (FT-IR) spectroscopy and the detection of Fe ${ }^{3^{+}}$impurities desorption using atomic absorption spectroscopy (AAS). The maximum purification product of $\mathrm{SiO}_{2}$ gel by using the mixed-solution of $\mathrm{HF}$ and $\mathrm{HCl}$, was done at the composition of $1 \% \mathrm{HF}$ and $1 \mathrm{~N} \mathrm{HCl}$ as well as temperature of $80{ }^{\circ} \mathrm{C}$ for 8 hours. The purification process conducted at the condition of 5\% HF, temperature of $100{ }^{\circ} \mathrm{C}$ and contact time of 10 hours would damage the functional groups of xylanol, siloxane and water.The successful of purification needs to conduct FTIR tracking on the purification product at the wavelengths of $3448 \mathrm{~cm}^{-1}, 1635 \mathrm{~cm}^{-1}, 1103 \mathrm{~cm}^{-1}$ and $462 \mathrm{~cm}^{-1}$ which was the $\mathrm{SiO}_{2}$ characteristic. The appearance of peaks around the wavelength of $1103 \mathrm{~cm}-1$ could be predicted that the sample containing the mineral of a quartz type. The purification processing of $\mathrm{SiO}_{2}$ gel conducted at the optimum condition, could obviously remove the impurities in the filtrate as the amount of $60.4 \mathrm{ppm} \mathrm{Fe}{ }^{3+f r o m ~} 100 \mathrm{mg} / \mathrm{gr} \mathrm{SiO} 2$ residue.

Keywords: $\mathrm{SiO}_{2}$ gel, xylenol, siloxane, water group, FTIR, AAS. 


\section{PENDAHULUAN}

Silika atau $\mathrm{SiO}_{2}$ banyak digunakan di dunia industri seperti pengisi katalis, bahan adsorben, kromatografi [1], Sel surya, material biosensor [2], nanokomposite [3] dan sebagainya. Hal ini karena $\mathrm{SiO}_{2}$ memiliki energi bebas yang tinggi, sehingga mudah diserap air di bawah suhu kamardan membentuk hidroksilasi. Silika dalam sistem kimia permukaan terdiri dari kelompok gugus fungsi siloksan (三Si-O-Si $\equiv)$ dan gugus silanol ( $(=\mathrm{Si}-\mathrm{OH})$ [1]. Kelompok gugus air $(\mathrm{OH})$ dan silanol $(\equiv \mathrm{Si}-\mathrm{OH})$ keberadaannya dipermukaan silika dapat mempengaruhi reaksi yang digunakan untuk merubah permukaan dengan alkil sesuai rekayasa seperti untuk obat [4]. Permukaan dengan gugus air $(\mathrm{OH})$ dan grup silanol $(\equiv \mathrm{Si}-\mathrm{OH})$ peran penting dalam selektivitas dan termodinamika pada proses modifikasi, perakitan maupun rekayasa pada permukaan silika. Oleh karena itu, penelitian dan pengetahuan tentang gugus air $(\mathrm{OH})$ dan grup silanol $(\equiv \mathrm{Si}-\mathrm{OH})$ harus menjadi perhatian bagi para perekayasa untuk menjadi bahan baru [3]. Sedangkan istilah permukaan itu sendiri akan dipahami sebagai batas padatan yang nonporous. Sedangkan permukaan itu sendiri diartikan sebagai batas yang tahan dan tidak tembus terhadap adsorbat nitrogen (nitrogen cair) yang sering digunakan untuk mengukur luas permukaan dengan alat surface area meter [5]. Permukaan silika yang aktif akan dipenuhi oleh gugus fungsi siloksan (ESi-O-SiE) dan gugus silanol $(\equiv \mathrm{Si}-\mathrm{OH})$ serta gugus air $(\mathrm{OH})[5]$. Bahkan bila terdapat sejumlah kecil material anorganik ataupun organik dari eksternal permukaan, maka proses ini bisa dikatakan sebagai permukaan yang termodifikasi atau terekayasa [6]. Maka penelitian tentang kimia permukaan $\mathrm{SiO} 2$ sangat menarik untuk dilakukan, yang bertujuan untuk rekayasa bahan baru yang bermanfaat dimasa mendatang.

Metarulgical Test Work (MTW) pasir zirkon dari Landak Kalimantan Barat yang telah dilakukan di Pusat Sains dan Teknologi Akselerator (PSTA) - BATAN Yogyakarta dengan umpan $500 \mathrm{gr}$, dan menghasilkan $420 \mathrm{gr}$ $\mathrm{SiO}_{2}$ gel berwarna putih kekuningan. Produk samping $\mathrm{SiO}_{2}$ gel tersebut diproduksi terus menerus dan ditampung berupa limbah padat yang volumenya semakin banyak, tetapi sayang kemurnianya masih rendah [7]. Menurut Zhang [8], diperkirakan produk samping $\mathrm{SiO} 2$ gel tersebut masih mengandung $\mathrm{ZrO}_{2}, \mathrm{TiO}_{2}$ dan $\mathrm{Fe}_{2} \mathrm{O}_{3}$ cukup banyak, karena bahan baku proses pemurnian berasal dari pasir zirkon.

Terdapat beberapa literature tentang pemurnian $\mathrm{SiO}_{2}$ [9-12], tetapi pelaksanaannya cukup sulit dan memakai bahan kimia yang mahal. Metode pemurnian yang sederhana memakai pelarut campuran asam HF dan $\mathrm{HNO}_{3}$ dan memakai alat Teflon Bomb ternyata cukup andal. Metoda ini dipilih karena sesuai dengan sarana dan prasarana laboratorium di Bidang Teknologi Proses PSTA - BATAN, Yogyakarta. Keberhasilan pemurnian $\mathrm{SiO}_{2}$ gel tersebut perlu diikuti dengan rekam jejak dari setiap tahapan perlakuan proses. Rekam jejak tersebut akan membantu peneliti sejauh mana penelitian cukup dilakukan dan dianggap optimal. Sehingga efisiensi suatu penelitian berbasis waktu dan biaya dapat tercapai. Beberapa peneliti telah memilih perekaman jejak gugus silanol ( $(\mathrm{Si}-\mathrm{OH})$ serta gugus air $(\mathrm{OH})$ di permukaan silika memakai Raman spektroskopi [13], nuclear magnetic resonance (NMR) dan UV-Vis spektroskopi [14], serta fourier- transform infrared (FT-IR) spectroscopy [1]. Maka tujuan dari penelitian ini adalah untuk melakukan perekaman jejak gugus silanol $(\equiv \mathrm{Si}-\mathrm{OH})$ serta gugus air $(\mathrm{OH}) \mathrm{di}$ permukaan produk hasil pemurnian $\mathrm{SiO}_{2}$ gel. Sebagai parameter proses dilakukan fungsi suhu, waktu dan konsentrasi asam $\mathrm{HF}$, sedangkan pelepasan ion $\mathrm{Fe}^{3+}$ dari permukaan $\mathrm{SiO}_{2}$ gelakan diikuti dengan metoda serapan atom.

\section{METODOLOGI}

\section{Bahan}

Bahan-bahan yang dipergunakan meliputi umpan berupa $\mathrm{SiO}_{2}$ gel hasil proses klorinasi di kelompok proses pemurnian zirkonium, bidang teknologi proses PSTA-BATAN Yogyakarta. Asam fluorida dan $\mathrm{HNO}_{3}$, pelet $\mathrm{KBr}, \mathrm{AgNO}_{3}$ buatan $\mathrm{E}$ Merck, gas asetilen dan aquadest buatan lokal laboratorium PSTA.

\section{Alat}

Alat yang dipergunakan berupa seperangkat alat teflon bomb digaster yang dilengkapi pengatur suhu berupa oven dengan suhu maksimal $150^{\circ} \mathrm{C}$. Timbangan Sartorius 4 digit, seperangkat fourier transform infra red (FTIR) IRTracer-100 buatan Shimadzu dan spektrometer serapan atom (SSA) tipe 50AA buatan Varian Techtron. 


\section{Tata kerja}

Sebanyak $500 \mathrm{gr}$ sample $\mathrm{SiO}_{2}$ gel di treatment dengan air hangat $\left(70{ }^{\circ} \mathrm{C}-80^{\circ} \mathrm{C}\right)$ sebanyak $100 \mathrm{ml}$ hingga terbebas dari sisa ion $\mathrm{Cl}^{-}$. Sampel dikeringkan dalam oven pada suhu $110{ }^{\circ} \mathrm{C}$ selama 8 jam. Sampel sebanyak $2 \mathrm{gr}$ dikeringkan pada Teflon bomb digaster dan ditambah campuran asam yang terdiri $5 \mathrm{ml} \mathrm{HF} \mathrm{40 \%}$ dan $5 \mathrm{ml} \mathrm{HNO}{ }_{3} 1 \mathrm{~N}$. Teflon bomb digaster ditutup, kemudian dimasukkan ke dalam oven dipanaskan pada suhu $100{ }^{\circ} \mathrm{C}$ selama $5 \mathrm{jam}$. Pengerjaan sampel diulang dengan variasi suhu, waktu kontak dan konsentrasi HF. Hasil yang diperoleh ditempatkan hasil di dalam saringan memakai kertas saring Whatman 42 , dan dibilas dengan aquades beberapa kali untuk menghilangkan sisa asam. Selanjutnya dikeringkan di dalam oven pada $110^{\circ} \mathrm{C}$ selama 8 jam. Produk akhir ditimbang dan dianalisis karakterisasinya dengan FTIR.

\section{HASIL DAN PEMBAHASAN}

\section{Rekam Jejak Data FTIR}

Pemurnian cuplikan $\mathrm{SiO}_{2}$ gel yang dilakukan memakai Teflon bomb digaster pada dasarnya seperti digesti biasa. Tetapi proses tersebut dilakukan pada suhu yang rendah, ruang tertutup dan waktu yang cukup lama. Sebagai permulaan pemurnian dilakukan dengan variasi waktu kontak dengan kondisi parameter tetap HF $5 \%$ dan $\mathrm{NHO}_{3} 1 \mathrm{~N}$, suhu $80^{\circ} \mathrm{C}$ sedangkan waktu kontak sebagai parameter peubah.

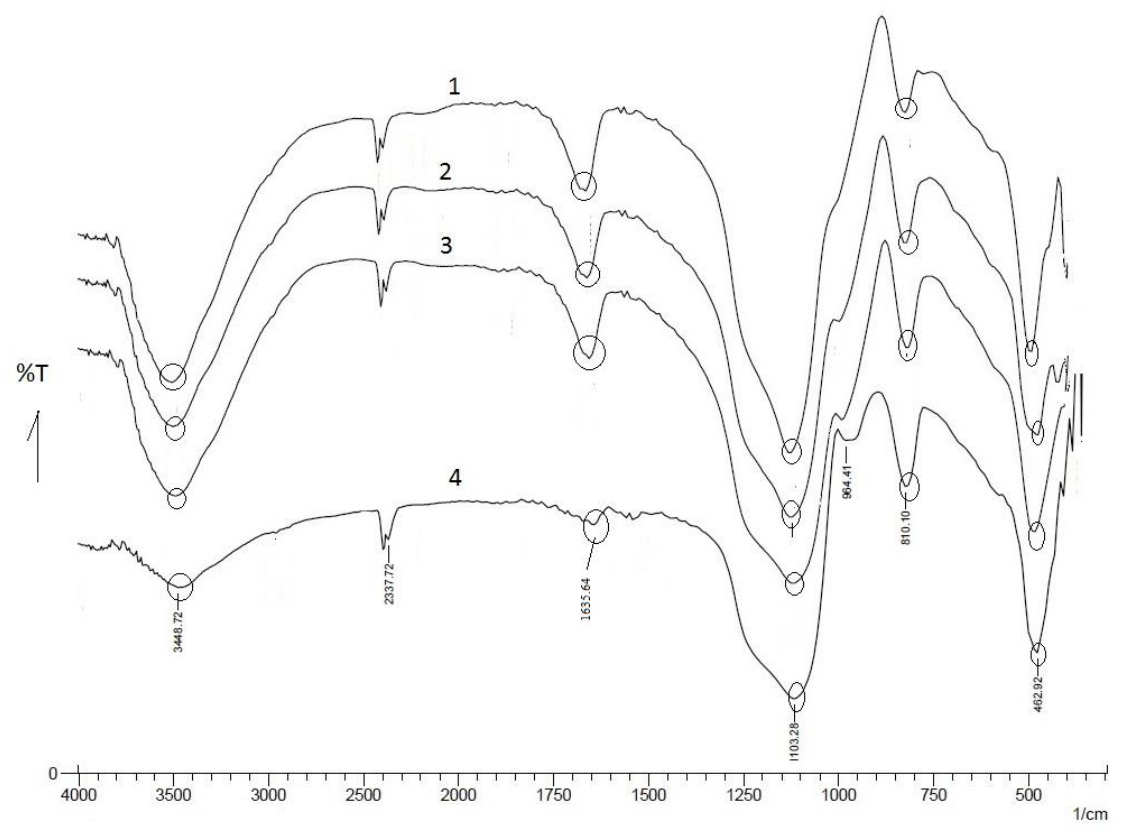

Gambar 1. Pola rekam jejak FTIR kimia permukaan $\mathrm{SiO}_{2}$ gel sebagai fungsi waktu kontak.

Pada gambar 1 dapat diperlihatkan pengaruh pola rekam jejak permukaan $\mathrm{SiO}_{2}$ gel dengan $\mathrm{FTIR}$, dengan variable waktu kontak (1) 1 jam, (2) 5 jam, (3) 8 jam dan (4) 10 jam. Rekam jejak FTIR tersebut menunjukkan bahwa secara fisik kelompok silanol $(\equiv \mathrm{Si}-\mathrm{OH})$ dan gugus air $(\mathrm{OH})$ terdapat di semua variable waktu kontak. Hal ini terlihat di sekitar panjang gelombang $3448 \mathrm{~cm}^{-1}$, dan diperkuat di munculnya puncak di sekitar $1635 \mathrm{~cm}^{-1}$. Dengan demikian secara kimia kelompok air terdapat di permukaan $\mathrm{SiO}_{2}$ gel [1]. Selanjutnya pada panjang gelombang $1103 \mathrm{~cm}^{-1}$ yang merupakan vibrasi perenggangan dan diperkuat adanya vibrasi tekuk di 462 $\mathrm{cm}-1$ menunjukkan adanya gugus siloksan dengan bentuk $\equiv \mathrm{Si}-\mathrm{O}-\mathrm{Si} \equiv$ [15]. Pada panjang gelombang $1103 \mathrm{~cm}-1$ tersebut dapat diprediksi terdapatnya mineral jenis a quartz [16]. Kemudian adanya puncak di sekitar panjang gelombang $964 \mathrm{~cm}-1$ dan $810 \mathrm{~cm}-1$, dapat diartikan bahwa permukaan $\mathrm{SiO}_{2}$ gel terdapat gugus vibrasi perenggangan dari gugus $\equiv \mathrm{Si}-\mathrm{OH}$ [1]. Pada Gambar 1 diperlihatkan pada panjang gelombang $2337 \mathrm{~cm}^{-1}$ diprediksi merupakan vibrasi tekuk Si-O dari siloksan. 
Selanjutnya pada Gambar 1, diperlihatkan bahwa pada waktu kontak 10 jam semua gugus aktif di permukaan SiO2gel mengalami penurunan \% T. Hal ini karena lamanya waktu kontak akan semakin rusaknya permukaan $\mathrm{SiO}$ gel karena terjadinya reaksi [17],

$$
\mathrm{SiO}_{2}+4 \mathrm{HF} \leftrightarrow \mathrm{SiF}_{4}+2 \mathrm{H}_{2} \mathrm{O}
$$

Akibat reaksi di atas menurut Stephen [17], ion $\mathrm{F}^{-}$akan menyebabkan kerusakan elektron orbital oksigen baik gugus silanol ( $(\mathrm{Si}-\mathrm{OH})$, gugus siloksan ( $(\mathrm{Si}-\mathrm{O}-\mathrm{Si} \equiv)$ dan gugus air $(-\mathrm{OH})$. Pada reaksi di atas akan terjadi melemahkan ikatan oksigen dengan adanya hidrogen. Akibatnya terjadi pelepasan Si dan hidrogen kedalam larutan, membentuk senyawa $\mathrm{SiF}_{4}$ dan $\mathrm{H} 2 \mathrm{O}$ (reaksi 1). Hal ini menjawab mengapa hasil rekam jejak untuk variable waktu kontak 10 jam akan menurun.

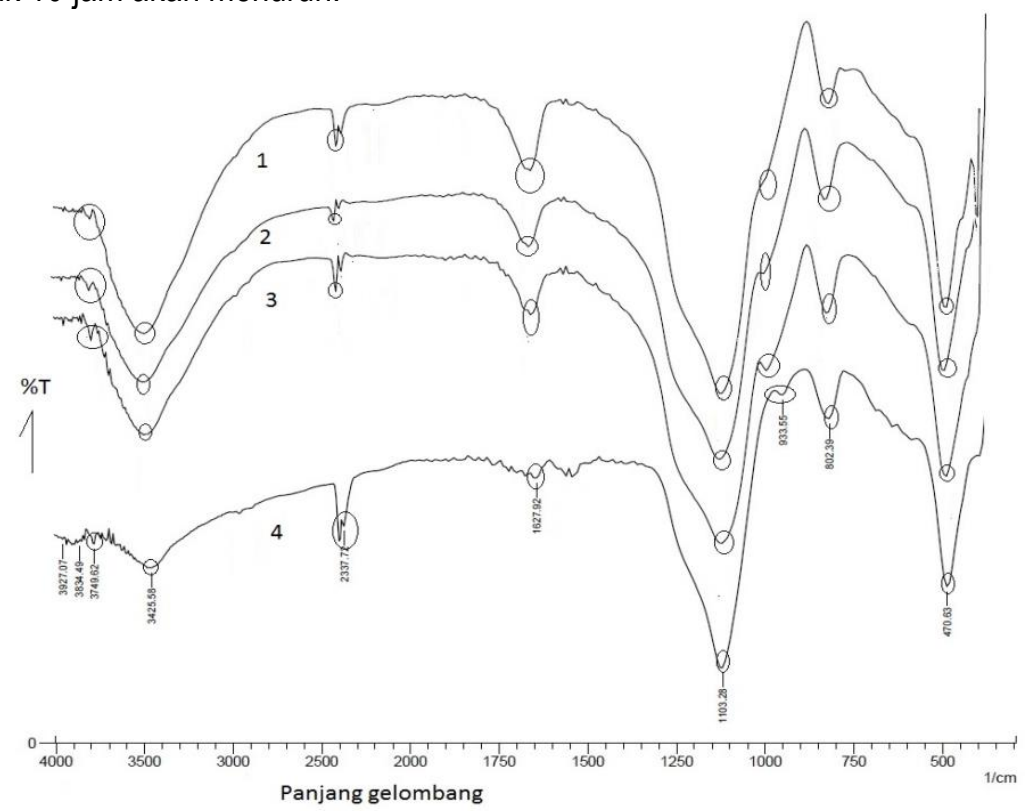

Gambar 2. Pola rekam jejak FTIR kimia permukaan $\mathrm{SiO}_{2}$ gel sebagai fungsi konsentrasi HF.

Pada Gambar 2 dapat diperlihatkan rekam jejak FTIR sebagai fungsi variable konsentrasi HF masingmasing dengan konsentrasi HF (1) $0,1 \%$, (2) $0,5 \%$, (3) 1,0\% dan (4) $5 \%$. Seperti halnya Gambar 1, puncak spesifik gugus-gugus silanol (三Si-OH), gugus siloksan (三Si-O-Si $\equiv)$ dan gugus air (-OH) terdapat pada Gambar 2. Bahkan pada panjang gelombang $3749 \mathrm{~cm}^{-1}$ merupakan grup silanol (三Si-OH) organo silikon yang berindikasi ikatan dengan logam pengotor [18]. Pada Gambar 2, terlihat bahwa pada konsentrasi HF 5\% rekam jejaknya mempunyai \% T yang berbeda dengan yang lain. Hal ini terutama pada panjang gelombang $3425 \mathrm{~cm}^{-1}$ dan 1627 $\mathrm{cm}^{-1}$, yang merupakan karakteristik dari gugus air $(\mathrm{OH})$. Hal ini karena terbentuknya dimer siloksan dipermukaan $\mathrm{SiO}_{2}$ gel yang reaksinya [19],

$$
\mathrm{OH}+\equiv \mathrm{Si}-\mathrm{O}-\mathrm{Si} \equiv \leftarrow\left[\begin{array}{c}
\mathrm{OH} \\
\mathrm{I} \\
\mathrm{I} \mathrm{Si}- \\
\mathrm{I} \\
\mathrm{O}-\mathrm{Si} \equiv
\end{array}\right]^{-}
$$

Dengan terbentuknya dimer siloksan tersebut akan mengakibatkan menurunnya \% T pada panjang gelombang $3425 \mathrm{~cm}^{-1}$ dan $1627 \mathrm{~cm}^{-1}$. Sebaliknya pada panjang gelombang $2337 \mathrm{~cm}^{-1}$ tampak terjadi sedikit kenaikan \% T. Hal ini kemungkinan karena terjadinya pelepasan donor proton oleh siloksan (三Si-O-Si adanya ion F- yang cukup dominan membentuk vibrasi tekuk Si-O. Akibatnya pada panjang gelombang $2337 \mathrm{~cm}$ 1 mengalami sedikit kenaikan dan terjadi reaksi sbb [17]:

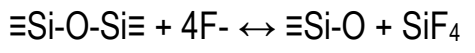




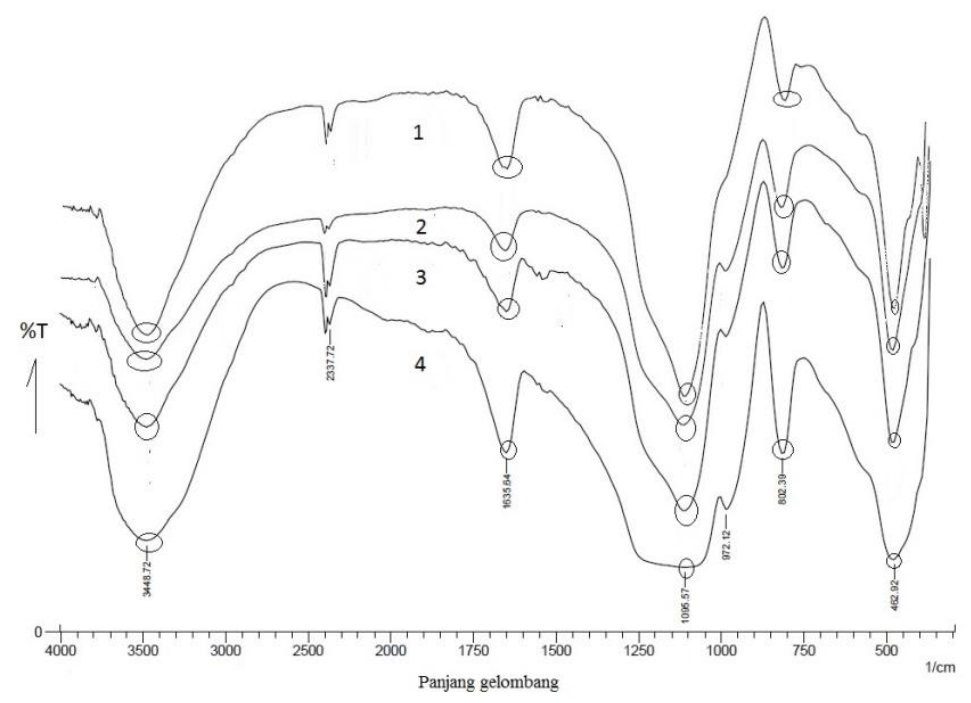

Gambar 3. Pola rekam jejak FTIR kimia permukaan $\mathrm{SiO}_{2}$ gel sebagai fungsi suhu.

Pada Gambar 3 dapat diperlihatkan rekam jejak FTIR sebagai fungsi variable suhu masing-masing di (1) $60{ }^{\circ} \mathrm{C}$, (2) $70^{\circ} \mathrm{C}$ (3) $80^{\circ} \mathrm{C}$ dan (4) $100^{\circ} \mathrm{C}$. Seperti halnya Gambar 1 dan 2, puncak spesifik gugus-gugus silanol $(\equiv \mathrm{Si}-\mathrm{OH})$, gugus siloksan $(\equiv \mathrm{Si}-\mathrm{O}-\mathrm{Si} \equiv)$ dan gugus air $(-\mathrm{OH})$ terdapat juga pada Gambar 3. Pada Gambar 3 ternyata pada pemanasan $100{ }^{\circ} \mathrm{C}$, rekam jejak permukaan $\mathrm{SiO}_{2}$ gel khususnya di panjang gelombang $1103 \mathrm{~cm}^{-1}$ mengalami puncak yang memanjang. Hal ini kemungkinan dikarenakan adanya relokasi dan penambahan pada gugus siloksan ( $(=\mathrm{Si}-\mathrm{O}-\mathrm{Si} \equiv)$ pada permukaan $\mathrm{SiO}_{2}$ gel. Relokasi diakibatkan bergabungnya 2 gugus silanol (三Si$\mathrm{OH}$ ) membentuk gugus siloksan ( $\mathrm{Si}-\mathrm{O}-\mathrm{Si} \equiv)$ dengan mengeluarkan air [19] yang reaksinya sbb:

$$
2(\equiv \mathrm{Si}-\mathrm{OH}) \leftrightarrow(\text { SSi-O-Si } \equiv)+\mathrm{H}_{2} \mathrm{O}
$$

\section{Desorpsi Pengotor $\mathrm{Fe}_{2} \mathrm{O}_{3}$}

Menurut Poernomo [7] dan Zhang [8], bahwa konsentrat zirkon sebagai bahan baku $\mathrm{SiO}_{2}$ gel sarat dengan pengotor $\mathrm{Fe}_{2} \mathrm{O}_{3}$ hingga mencapai $0,21 \%$. Selanjutnya penelitian Rahnama [20] yang telah membuat nano-partikel $\left(\mathrm{FeSO}_{4}, \mathrm{FeSO}_{4} / \mathrm{SiO}_{2}, \mathrm{FeSO}_{4} / \mathrm{SiO}_{2} / \mathrm{TiO}_{2}\right)$, yang dianalisis dengan $\mathrm{FTIR}$. Ternyata karakteristik $\mathrm{SiO}_{2}$ yang selalu muncul di sekitar panjang gelombang $3448 \mathrm{~cm}^{-1}, 1635 \mathrm{~cm}^{-1}, 1103 \mathrm{~cm}^{-1}$ dan $462 \mathrm{~cm}^{-1}$ tidak bisa membedakan cuplikan apakah nano-partikel tersebut bentuk $\mathrm{FeSO}_{4} / \mathrm{SiO}_{2}$ maupun $\mathrm{FeSO}_{4} / \mathrm{SiO}_{2} / \mathrm{TiO}_{2}$, dan Yaohui [21] juga tidak dapat membedakan karakteristik cuplikan antara $\mathrm{SiO}_{2}$ dengan $\mathrm{Fe}_{3} \mathrm{O}_{4} @ \mathrm{SiO}_{2}$. Menurut Tang [16], keberadaan pengotor $\mathrm{Fe}$ di dalam permukaan $\mathrm{SiO}_{2}$ akan terikat secara kimia pada gugus silanol dari reaksi,

$$
\begin{aligned}
& \equiv \mathrm{Si}-\mathrm{OH}+\mathrm{OH}-\leftrightarrow \text { ISi-O }+\mathrm{H}_{2} \mathrm{O} \\
& \equiv \mathrm{Si}-\mathrm{O}-+\mathrm{M}+\leftrightarrow \equiv \mathrm{Si}-\mathrm{OM} \ldots . . \quad \quad(\mathrm{M}=\mathrm{Fe})
\end{aligned}
$$

Berdasarkan uraian di atas dan hasil rekam jejak di Gambar 1, 2 dan 3 dilakukan analisis $\mathrm{Fe}^{3+}$ dengan alat AAS pada cuplikan filtrat dari variable konsentrasi HF (Gambar 2). Hasil desorpsi pengotor $\mathrm{Fe}_{2} \mathrm{O}_{3}$ sebagai ion $\mathrm{Fe}^{3+}$ dapat disajikan pada Gambar 4. 


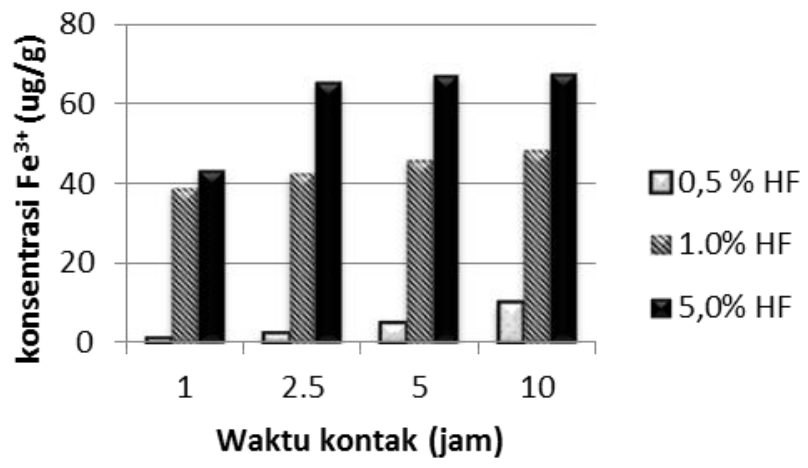

Gambar 4. Desorpsi ion $\mathrm{Fe}^{3+}$ dalam fitrat pemurnianSiO 2 gel sebagai fungsi konsentrasi $\mathrm{HF}$.

Dari Gambar 4 dapat diperlihatkan hubungan konsentrasi dan waktu kontak pada desorpsi yang dilakukan pada filtrat pemurnian pemurnian $\mathrm{SiO}_{2}$ gel sebagai fungsi konsentrasi $\mathrm{HF}$ dengan berbagai waktu kontak.Ternyata semakin tinggi konsentrasi $\mathrm{HF}$ konsentrasi ion $\mathrm{Fe}^{3+}$ yang terdesorpsi semakin tinggi. Kemudian semakin lama waktu kontak konsentrasi ion $\mathrm{Fe}^{3+}$ yang terdapat dalam filtrat akan semakin besar konsentrasinya. Penulis setuju dengan Kheloufi [12] bahwa pemurnian yang dilakukan pada quartz silica memakai pelarut campuran $\mathrm{HF} 20 \%$ dan $\mathrm{HCl} 1 \mathrm{~N}$, dapat menghilangkan pengotor Fe sebesar $40 \%$ secara catu.

\section{KESIMPULAN}

Pemurnian $\mathrm{SiO}_{2}$ gel dengan pelarut campuran $\mathrm{HF}$ dan $\mathrm{HCl}$, sebaiknya dilakukan pada komposisi $1 \% \mathrm{HF}$ dan $1 \mathrm{~N} \mathrm{HCl}$ pada suhu $80^{\circ} \mathrm{C}$ selama 8 jam. Pada keadaan proses pemurnian $5 \% \mathrm{HF}$, suhu $100{ }^{\circ} \mathrm{C}$ dan waktu kontak 10 jam akan memunculkan gugus silanol, siloksan dan grup air. Rekam jejak FTIR di panjang gelombang $3448 \mathrm{~cm}^{-1}, 1635 \mathrm{~cm}^{-1}, 1103 \mathrm{~cm}^{-1}$ dan $462 \mathrm{~cm}^{-1}$ yang merupakan karakteristik dari $\mathrm{SiO}_{2}$, ternyata dapat untuk memprediksi keberhasilan suatu proses pemurnian $\mathrm{SiO}_{2}$. Dengan munculnya puncak di sekitar panjang gelombang $1103 \mathrm{~cm}^{-1}$ dapat diprediksi cuplikan $\mathrm{SiO}_{2}$ mengandung mineral jenis a quartz. Proses pemurnian $\mathrm{SiO}_{2}$ gel yang dilakukan kondisi optimal, ternyata dapat menghilangkan pengotor dalam filtrat sebesar $60,4 \mathrm{ppm}$ $\mathrm{Fe}^{3+}$.

\section{UCAPAN TERIMAKASIH}

Dengan selesainya pembuatan makalah ini penulis mengucapkan banyak terimakasih kepada Dr. Susilo Widodo, Suyanti S.Si. dan Ir. Herry Poernomo MT masing-masing sebagai Kapus PSTA, Kabid BTP dan Kapok TPZ yang banyak membantu dalam hal pendanaan melalui DIPA 2017. Penulis juga sangat berterimakasih kepada saudari Hasna Irfantiningtyas Sari yang telah banyak membantu di laboratorium.

\section{DAFTAR PUSTAKA}

[1] L. Peng, W. Qisui, L. Xi, and Z. Chaocan, "Investigation of the states of water and $\mathrm{OH}$ groups on the surface of silica," Colloids Surfaces A Physicochem. Eng. Asp., vol. 334, no. 1-3, pp. 112-115, 2009.

[2] T. Isoda, R. Maeda, and A. Minohoshi, "Development of a Silica Surface Modified with Reactive Amino Group as an Immobilized Carrier for Use as Biosensor Material," vol. 27, no. 2, pp. 165-176, 2015.

[3] M. Praeger, I. L. Hosier, A. S. Vaughan, and S. G. Swingler, "The effects of surface hydroxyl groups in polyethylene-silica nanocomposites," 33rd Electr. Insul. Conf. EIC 2015, no. June, pp. 201-204, 2015. 
[4] X. Huang, N. P. Young, and H. E. Townley, "Characterization and Comparison of Mesoporous Silica Particles for Optimized Drug Delivery," Nanomater. Nanotechnol., vol. 4, p. 2, 2014.

[5] Iler, "the chemistry of silica chapter 6: The Surface Chemistry of Silica," Chem. Silica, pp. 622-729, 1979.

[6] W. Y. D. Yong, Z. Zhang, G. Cristobal, and W. S. Chin, "One-pot synthesis of surface functionalized spherical silica particles," Colloids Surfaces A Physicochem. Eng. Asp., vol. 460, no. October, pp. 151157, 2014.

[7] Poernomo.H, "Informasi umum zirkonium," BADAN TENAGA NUKLIR NASIONAL, PUSAT TEKNOLOGI AKSELERATOR DAN PROSES BAHAN. JI. Babarsari Kotak Pos 6101 Ykbb Yogyakarta $55281,2012$.

[8] J. Zhang, L. Wang, and D. Jiang, "Decomposition process of zircon sand concentrate with $\mathrm{CaO}-\mathrm{NaOH}$," Rare Met., vol. 31, no. 4, pp. 410-414, 2012.

[9] I. B. Koki, "Efficiencies of Acid Digestion / Leaching Techniques in the Determination of Iron Concentrations in Soils from Challawa Industrial Estate Kano, Nigeria," Merit Res. J. Environ. Sci. Toxicol., vol. 3, no. 5, pp. 65-71, 2015.

[10] M. Abdisy, S. Al, L. P. Setiawan, M. Utami, and W. Trisunaryanti, "Study of acid leaching in the preparation of silicon from lapindo mud," Int. J. Acad. Sci. Res., vol. 2, no. 4, pp. 31-36, 2014.

[11] M. Khalifa, M. Hajji, and H. Ezzaouia, "Impurity removal process for high-purity silica production by acid leaching," EPJ Web Conf., vol. 29, pp. 2-5, 2012.

[12] A. Kheloufi, Y. Berbar, A. Kefaifi, S. A. Medjahed, and F. Kerkar, "Improvement of impurities removal from silica sand by using a leaching process," Chem. Eng. Trans., vol. 24, pp. 1513-1518, 2011.

[13] Y. Yue, Y. Bai, and J. J. Wang, "Application of raman spectroscopy for tracing the status of silica fume in cementitious materials," Int. Conf. Durab. Concr. Struct. ICDCS 2016, no. ii, pp. 1-5, 2016.

[14] M. Badertscher, P. Bühlmann, and E. Pretsch, Structure Determination of Organic Compounds. 2009.

[15] L. T. Zhuravlev, "The surface chemistry of amorphous silica," Colloids Surf., vol. 173, pp. 1-38, 2000.

[16] C. Tang et al., "Surface chemistry and reactivity of SiO2 polymorphs: A comparative study on a-quartz and a-cristobalite," Appl. Surf. Sci., vol. 355, pp. 1161-1167, 2015.

[17] T. Stephen, "Thecorrosion of silicate materials by hydrogen gas and hydrofluoric Acid,thesis of University of California, Material \& molecular Research Division" 2011.

[18] P. J.Launer, "Infrared analysis of organosilocon caompond: spectra-structure correlation,Laboratory for Materials, Inc, Burnt Hills University, New York" 2015.

[19] A. A. Christy, "The Nature of Silanol Groups on the Surfaces of Silica, Modified Silica and Some Silica Based Materials," Adv. Mater. Res., vol. 998-999, pp. 3-10, 2014.

[20] H. Rahnama, A. Sattarzadeh, F. Kazemi, N. Ahmadi, F. Sanjarian, and Z. Zand, "Comparative study of three magnetic nano-particles (FeSO4, $\mathrm{FeSO} 4 / \mathrm{SiO} 2, \mathrm{FeSO} / \mathrm{SiO} 2 / \mathrm{TiO} 2)$ in plasmid DNA extraction," Anal. Biochem., vol. 513, no. September, pp. 68-76, 2016.

[21] Y. Xu, Y. Zhou, W. Ma, S. Wang, and S. Li, "Applied Surface Science Highly sensitive and selective OFF-ON fluorescent sensor based on functionalized Fe 304 @ SiO 2 nanoparticles for detection of Zn $2+$ in acetonitrile media," Appl. Surf. Sci., vol. 276, no. 2013, pp. 705-710, 2013. 